\title{
Origin and Distribution of Cr2, a Gene for Resistance to White Pine Blister Rust in Natural Populations of Western White Pine
}

\author{
Bohun B. Kinloch, Jr., Richard A. Sniezko, and Gayle E. Dupper
}

First and third authors: Institute of Forest Genetics, U.S. Department of Agriculture (USDA), Forest Service, Pacific Southwest Research Station, Berkeley, CA 94701 and Placerville, CA 95667; and second author: Dorena Genetic Resources Center, USDA Forest Service, Cottage Grove, OR 97424.

Accepted for publication 15 January 2003.

\section{ABSTRACT}

Kinloch, B. B., Jr., Sniezko, R. A., and Dupper, G. E. 2003. Origin and distribution of $\mathrm{Cr} 2$, a gene for resistance to white pine blister rust in natural populations of western white pine. Phytopathology 93:691-694.

The distribution and frequency of the $\mathrm{Cr} 2$ gene for resistance to white pine blister rust (Cronartium ribicola) in western white pine (Pinus monticola) was surveyed in natural populations of the host by inoculation of open-pollinated seedlings from 687 individual seed parents from throughout most of the species' range. Because $\mathrm{Cr} 2$ is dominant and results in a conspicuous hypersensitive reaction (HR) in pine needles, the phenotype can readily be detected in offspring of susceptible seed parents fertilized by unknown $\mathrm{Cr} 2$ donors in the ambient pollen cloud. Gametic frequencies of $\mathrm{Cr} 2$ were thus determined as the proportion of total challenged seedlings that were pollen receptors exhibiting the $\mathrm{Cr} 2$ phenotype.
Zygotic frequencies, the proportion of seed parents with progeny that segregated in Mendelian ratios for the $\mathrm{Cr} 2$ phenotype to the total number of parents, were a complementary, though less precise, measure. $\mathrm{Cr} 2$ frequency was rare overall, ranging from 0.004 to 0.008 in the Sierra Nevada to about 0.001 in the central Cascade Range; it was undetectable further north in the Cascades, as well as in the Rocky Mountains and Coast Mountains of the United States and Canada. The diminishing frequency of $\mathrm{Cr} 2$ from the southern and central Sierra Nevada northward mirrors that of $\mathrm{Cr} 1$ in sugar pine ( $P$. lambertiana) and points to this region as the origin of both genes. We rationalize that this coincidence may have resulted from protection that these genes may have conferred on both species to an endemic pine stem rust congeneric with $C$. ribicola (C. occidentale) in recent geologic epochs.
White pine blister rust, caused by Cronartium ribicola, was introduced into western North America almost a century ago and has had a devastating impact on western white pine (Pinus monticola), a species of major economic and ecological importance. Up to $95 \%$ of once nearly pure stands have been destroyed in the northern Rocky Mountains and the effect on natural regeneration is altering patterns of succession (10). Genetic resistance is considered the most feasible method to control the disease and help restore this once magnificent species to its former ecological role.

Discovery of $\mathrm{Cr} 2$, a major gene for resistance to white pine blister rust in western white pine, was made in a small, naturally regenerated stand in the Western Cascades of Southwest Oregon (8). Known as the Champion Mine site, this stand is in an environment unusually favorable for spread and intensification of white pine blister rust, lying near the top of a steep, moist, narrow canyon with a northwest aspect that supports abundant stands of Ribes bracteosum and other alternate host Ribes spp. Successive epidemic waves of rust since about 1940 eliminated most of the white pines, leaving a naturally selected residual population of highly resistant phenotypes. Most of this parental population was subsequently determined to carry $\mathrm{Cr} 2$ in heterozygous form (8).

The distribution of this gene elsewhere in western white pine populations is unknown, but is of both theoretical and practical interest because its use to mitigate the impact of white pine blister rust will depend on locating and selecting $\mathrm{Cr} 2$ parents adapted to local site conditions. We undertook this investigation to map the distribution and frequency of $\mathrm{Cr} 2$ throughout the range of western

Corresponding author: B. Kinloch, Jr.; E-mail address: bkinloch@fs.fed.us

Publication no. P-2003-0331-04R

This article is in the public domain and not copyrightable. It may be freely reprinted with customary crediting of the source. The American Phytopathological Society, 2003. white pine in order to assess the feasibility of deploying this gene for practical control of the disease, and also to adduce evidence as to its geographic and evolutionary origin. A comparable study of the $\mathrm{Cr} 1$ gene in sugar pine ( $P$. lambertiana) has been made (4).

\section{MATERIALS AND METHODS}

Open-pollinated seed of western white pine from individual parents was provided by various cooperators. These collections covered a substantial portion of the species' range (Fig. 1), although significant gaps existed. For example, no seed was available from the northern Rocky Mountains of Idaho, where selection and breeding for resistance in this species was begun (1), and there were only three stand collections from the Sierra Nevada in California. Most of the 695 parents sampled were scattered individuals, but some were grouped in stands. The largest group consisted of 62 seed parents from Latour Demonstration State Forest in the southern Cascade Range.

Seeds were cold stratified for 120 days and sown into 10-cubicinch Ray Leach containers (Stewe \& Sons, Corvallis, OR). Amounts and germinability of different seed lots varied, but an average of approximately 38 seedlings per parent were available for assessment.

Seedlings from individual seed parents were inoculated with blister rust from a source known to be avirulent to $\mathrm{Cr} 2$, from $\mathrm{El}$ Dorado County, California (8). Detached leaves of $R$. nigrum bearing mature telia were suspended over seedlings in the cotyledon or early primary needle stage and incubated in darkness at $15 \pm$ $0.6^{\circ} \mathrm{C}$ in a dew chamber (Model I-35D; Percival Manufacturing Co., Boone, IA) for $48 \mathrm{~h}$ (5). After inoculation, seedlings were returned to the greenhouse.

Incipient symptoms became visible within 2 weeks and were definitive by 6 weeks. The two interaction phenotypes scored were bright yellow (or occasionally red) needle spots typical of 
compatible (susceptible) reactions, or initial yellow spots that soon developed necrosis at the margins, which then progressed inward to fill the spot. These spots did not enlarge beyond the necrotic margin and indicated an incompatible hypersensitive reaction (HR). No seedlings with HR spots subsequently developed stem symptoms.

Families that segregated in an approximate 1:1 ratio of yellow spots to HR spots identified seed parents heterozygous for $\mathrm{Cr} 2$. The zygotic frequency of $\mathrm{Cr} 2$ in any population was the number of heterozygotes observed divided by twice the number of seed parents evaluated. An alternative measure was the gametic frequency, assessed by estimating the incidence of $\mathrm{Cr} 2$ in the ambient pollen cloud. Here, seedlings with HR phenotypes (usually no more than one or two) in families from nonsegregating, susceptible (cr2cr2) genotypes were presumed to have derived their resistance from unknown $\mathrm{Cr} 2$ pollen donors. These $\mathrm{Cr} 2$ pollen receptors were counted, divided by the total number of symptomatic seedlings from the seed parent, and averaged over all seed parents from a given region.

\section{RESULTS}

Estimates of both zygotic and gametic frequencies of $\mathrm{Cr} 2$ are provided in Table 1. Of the two measures, the more reliable estimate is the gametic frequency, not only because the sample size is much larger, but also because it is unbiased, representing a random sample of the alleles in the ambient pollen cloud surrounding each seed parent. Estimates from seed parent genotypes (zygotic frequencies) on the other hand are subject to greater sampling error and bias from phenotypic selection, i.e., the tendency to

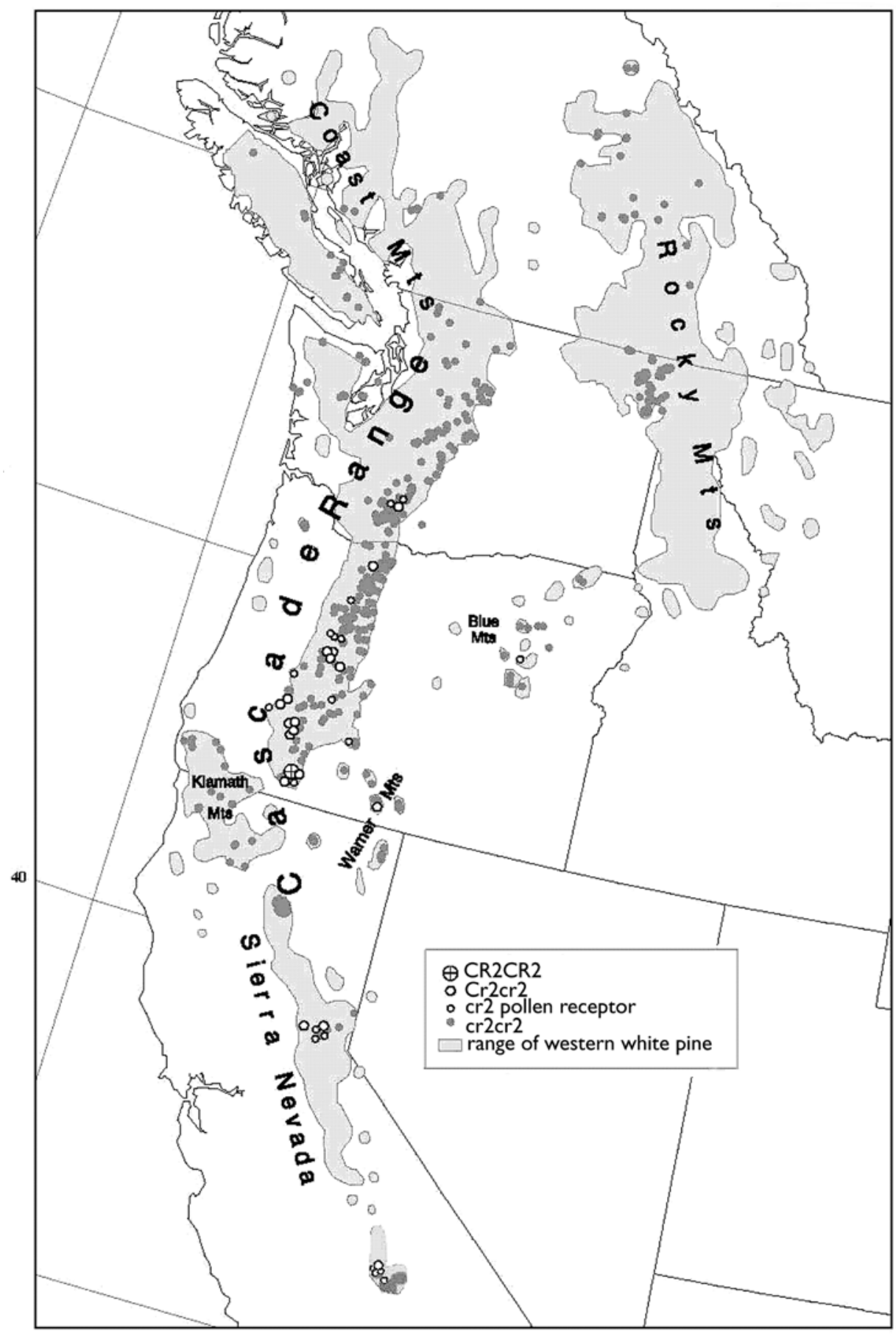

Fig. 1. Distribution and relative frequencies of genotypes at the $\mathrm{Cr} 2$ locus in western white pine (Table 1 provides $\mathrm{Cr} 2$ allele frequencies). 
avoid obviously infected trees (3). Genetic substructuring in local neighborhoods (for example, from past inbreeding) could still cause some bias, but this would be mitigated by averaging over more extended areas. Our sample sizes were usually not sensitive to frequencies of $\mathrm{Cr} 2$ below 0.001 .

The distribution of $\mathrm{Cr} 2$ appeared to lie in two main clusters (Fig. 1; Table 1): one in the Sierra Nevada, where gametic frequencies ranged from 0.005 to 0.008 , and the other in the central Cascades, from southern Oregon to southern Washington, where mean gametic frequency was approximately 0.001 (Table 1). Between these two areas was a gap extending from the southern extremity of the Cascades (Latour State Forest) through the Klamath and Warner Mountains, where $\mathrm{Cr} 2$ was detected only in a single heterozygous seed parent in the Warner Mountains. It was also undetected north of the central Cascades, in the Coast Mountains of British Columbia, and in the northern Rocky Mountains of British Columbia and northeastern Washington.

In the central Cascades, zygotic frequencies of seed parents, including those selected for above average performance of offspring in earlier screening tests (nursery selects), were nearly 20 times greater than gametic frequencies (Table 1). Zygotic frequencies were highest by far $(0.423)$ in the Champion Mine population, a stand that had undergone strong natural selection after repeated epidemics of blister rust had killed most of the trees. Surviving and phenotypically resistant seed parents were selected from this stand in the late 1950s, and estimates of zygotic frequency were derived from controlled pollinated families from matings among them, reported earlier (8). Most parents (22 out of 26 evaluated) were heterozygous for $\mathrm{Cr} 2$; no homozygotes were identified. Because these evaluations were made from controlled pollinations, no estimates of gametic frequencies were possible. Subsequently, this residual group of resistant parents at Champion Mine came under attack by a race of rust with specific virulence to $\mathrm{Cr} 2$ (6), the last one dying in 1994.

The disparity between zygotic and gametic frequencies was generally much less in Sierra Nevada than in central Cascade populations (Table 1).

\section{DISCUSSION}

$\mathrm{Cr} 2$ is rare in western white pine populations; its existence was suspected only after the discovery of the small population of resistant phenotypes at Champion Mine and confirmed by Mendelian segregation of HR-type resistance in their full-sib offspring following artificial inoculation (8). We cannot of course prove that all of the HR phenotypes observed in our data represent $\mathrm{Cr} 2$, be- cause the same interaction phenotype to a particular pathogen can be controlled by different gene loci, as happens in many pathosystems. However, given the rarity of HR in these data, we consider the involvement of more than one locus highly unlikely.

Virtually all trees at Champion Mine lacking $\mathrm{Cr} 2$ were killed in successive waves of the epidemic. The observed zygotic frequency in this residual population was 0.42 , over 400 times greater than the gametic frequency for the central Cascades (0.0010; Table 1), suggesting the possibility that isolated pockets of western white pines with unusually high frequency of $\mathrm{Cr} 2$ may exist. The pre-epidemic frequency of $\mathrm{Cr} 2$ in the Champion Mine deme cannot be estimated without knowing how many susceptible (cr2cr2) genotypes were killed, but a crude estimate of the size of the base population is possible if we assume the null hypothesisthat the pre-epidemic gametic frequency at Champion Mine was no different than that in the central Cascades-and that this locus is in Hardy-Weinberg equilibrium. In this case, the expected proportion of heterozygotes would be approximately double the estimated $\mathrm{Cr} 2$ frequency or 0.0020 . Using this proportion and the 22 heterozygotes observed in the residual stand, the base population would have been about $10 \mathrm{~K}$ individual trees. Stand records and tree ring data of some of the parent trees indicate that the stand regenerated around 1920 on about 100 acres, thus averaging 1,000 trees per acre. This is a realistic figure for a naturally regenerated second growth stand and removes the necessity for invoking the preexistence of any extraordinary local concentration of $\mathrm{Cr} 2$. The fact that no homozygous resistant genotypes were detected implies, at the very least, that the frequency of $\mathrm{Cr} 2$ was quite low and perhaps no different than the gametic frequency. The great disparity between the observed zygotic frequency at Champion Mine and the gametic frequency in the surrounding region is best explained by the intense natural selection pressure this stand was subjected to in successive epidemic waves. By similar reasoning, artificial selection against rust-infected parents could account for the differences observed between zygotic and gametic frequencies elsewhere (for example, the central Cascades and nursery selects; Table 1). The effect of artificial selection in increasing zygotic frequencies has been clearly documented for $\mathrm{Cr} 1$ in sugar pine (3).

Gametic frequencies of $\mathrm{Cr} 2$ declined from almost 0.01 in the Sierra Nevada to 0.001 in the central Cascades and were undetectable most everywhere further north in the Cascades, Coast Mountains of British Columbia, and Rocky Mountains of eastern Washington and British Columbia (Table 1; Fig. 1). Between the Sierra Nevada and central Cascades was a gap, consisting of the southern Cascades, Klamath, and Warner mountains, where it was nearly

TABLE 1. Zygotic and gametic frequencies of $\mathrm{Cr} 2$ in natural populations of western white pine and confidence limits for gametic frequencies $\left(\mathrm{CL}_{g}\right)$

\begin{tabular}{|c|c|c|c|c|c|c|}
\hline \multirow[b]{2}{*}{ Mountain range $^{\mathrm{a}}$} & \multicolumn{4}{|c|}{$\mathrm{Cr} 2$ frequency } & \multicolumn{2}{|c|}{$\mathrm{CL}_{g}(95 \%)$} \\
\hline & Zygotic & $\left(n_{z}\right)^{\mathrm{b}}$ & Gametic & $\left(n_{g}\right)^{\mathrm{c}}$ & Lower & Upper \\
\hline Coast Mountains & 0.0000 & $(138)$ & 0.0000 & $(2,136)$ & 0.0000 & 0.0014 \\
\hline Rocky Mountains & 0.0000 & $(228)$ & 0.0000 & $(2,151)$ & 0.0000 & 0.0014 \\
\hline Blue Mountains & 0.0000 & $(38)$ & 0.0015 & (660) & 0.0002 & 0.0111 \\
\hline Warner Mountains & 0.0064 & $(156)$ & 0.0000 & $(2,045)$ & 0.0000 & 0.0015 \\
\hline Klamath Mountains & 0.0000 & (86) & 0.0000 & (921) & 0.0000 & 0.0032 \\
\hline \multicolumn{7}{|l|}{ Cascade Range } \\
\hline Northern & 0.0000 & $(180)$ & 0.0000 & $(3,196)$ & 0.0000 & 0.0009 \\
\hline Central & 0.0174 & $(460)$ & 0.0010 & $(8,603)$ & 0.0005 & 0.0020 \\
\hline Southern & 0.0000 & (124) & 0.0000 & $(4,616)$ & 0.0000 & 0.0006 \\
\hline Nursery selects & 0.0769 & $(78)$ & 0.0040 & $(2,236)$ & 0.0021 & 0.0078 \\
\hline Champion Mine ${ }^{\mathrm{d}}$ & 0.4231 & $(52)$ & nd & nd & $\ldots$ & $\ldots$ \\
\hline \multicolumn{7}{|l|}{ Sierra Nevada } \\
\hline Northern & 0.0588 & (34) & 0.0081 & (370) & 0.0026 & 0.0254 \\
\hline Southern & 0.0083 & (120) & 0.0046 & $(1,973)$ & 0.0023 & 0.0089 \\
\hline
\end{tabular}

a Compare with Figure 1.

b Number of seed parents genotyped multiplied by 2 .

c Number of open-pollinated seedlings genotyped from homozygous recessive (cr2cr2) parents.

${ }^{\mathrm{d}}$ Data obtained from Kinloch et al. (8). nd, not determined. 
undetectable, with only a single seed parent heterozygous for $\mathrm{Cr} 2$ in the Warner Mountains. However, this gap may be more apparent than real, because of insufficient samples to detect a gene at very low frequency. The southern Cascade Range was represented by a single intensively sampled stand of 62 seed parents, and the Klamath and Warner mountains by even fewer (though more widely distributed) parents. $\mathrm{Cr} 2$ frequency in the Blue Mountains of Oregon was about the same as in the central Cascades at equivalent latitude.

$\mathrm{Cr} 2$ is functionally indistinguishable from $\mathrm{Cr} 1$, the gene that confers resistance to white pine blister rust in sugar pine (7). Both are dominant and condition $\mathrm{HR}$ in foliar tissues, similar to $\mathrm{R}$ genes in other plant pathosystems. They are not the same allele, however-and may be at different gene loci-because they react differentially to different inoculum sources of blister rust (6). The two genes also share similarities in patterns of distribution. $\mathrm{Cr} 1$ forms a cline that starts at or below frequencies of about 0.005 at the northern part of sugar pine's range in the central and southern Cascades and rises steadily to a peak of 0.08 in the southern Sierra Nevada before declining to 0.02 to 0.03 in the Transverse and Peninsular ranges of southern California and then to undetectable levels in the Sierra San Pedro Martir of Baja California (4). Although $\mathrm{Cr} 2$ is at much lower frequency overall than $\mathrm{Cr} 1$, its greatest concentration is in the Sierra Nevada, where it is four to eight times greater than in the central Cascades. As with $\mathrm{Cr} 1$, this clearly implicates the Sierra Nevada as the probable center of origin of this gene. Both genes become increasingly diluted outward from the southern-central Sierra Nevada- $\mathrm{Cr} 1$ in both directions, north and south, and $\mathrm{Cr} 2$ to the north (the distribution of western white pine does not extend south of the southern Sierra Nevada).

This interpretation is consistent with the late Pleistocene history of western white pine, inferred from genetic data, which saw the species pushed to refugia in the Klamath floristic province of northern California and southern Oregon during the full glacial, from which it expanded to present northern limits during the Holocene. Evidence from isozyme marker loci, monoterpene distributions, and growth rate patterns all show relative uniformity in contemporary northern populations in contrast with much greater heterogeneity in the Sierra Nevada and a steep transition zone in the Klamath Mountains $(2,11,12)$. The progressive decline in frequency of both $\mathrm{Cr} 1$ and $\mathrm{Cr} 2$ northward from the Sierra Nevada follows a typical dilution pattern of genes undergoing rapid migration from their center of origin, as a function of genetic drift (9).

The most intriguing aspect of these $\mathrm{Cr}$ alleles is not that they are rare (though still far above typical rates of mutation, $\approx 10^{-6}$ ), but that they exist at all. Major genes with differential specificities are not expected in wild pathosystems of such recent contact between host and pathogen. The hypothesis that $\mathrm{Cr} 1$ may have played a role in protecting sugar pine against the endemic pinyon blister rust, $C$. occidentale, in recent geological epochs was based in part on overlapping distributions of sugar and pinyon pine $(P$. monophylla) during the Pleistocene (4). Western white pine presently overlaps sugar pine at its upper elevations in the Sierra Nevada and Cascades. The similarity in pattern of distribution of the two genes reinforces the hypothesis that they may have had a common selective agent.

Practical implications. Seed parents identified as having $\mathrm{Cr} 2$ by artificial inoculation of their offspring are currently being used for reforestation in parts of Oregon for short-term mitigation of blister rust damage. The simplicity and efficiency of the screening test makes this economically feasible wherever $\mathrm{Cr} 2$ frequencies approach $1 \%$. At this level, 1 in 50 candidates even randomly selected will have the allele, and considerably more than that will be identified in areas of moderate to heavy rust challenge, where phenotypic selection for resistance can be practiced. Unfortunate- ly, frequencies at or above $1 \%$ do not occur in the greater part of the commercial range of western white pine.

An alternative strategy for the long term is to identify large numbers of $\mathrm{Cr} 2$ pollen receptors from seed parents that do not themselves carry the allele and grow these to sexual maturity. In this approach, fewer seed parents need to be selected, though much greater numbers of seedlings per parent need to be screened. The candidate parents can be phenotypically selected for desirable traits other than rust resistance and could be expected to transmit half of their additive genetic variance for such traits to offspring. Most important, a broader genetic base for future breeding can be established, at least in areas from the Sierra Nevada to the central Cascades. Virtually any candidate tree can be expected to yield one or more pollen receptors if sufficient numbers of seedlings are screened. The sexual precocity and natural fecundity of western white pine assures that development of such a synthetic population could be achieved within one or two decades. Durable resistance for the long term will require combining major genes like $\mathrm{Cr} 2$ with other host resistance genes currently under investigation that are not specifically vulnerable to matching virulence genes in the pathogen.

\section{ACKNOWLEDGMENTS}

We thank the many cooperators who shared their seed inventories for this survey: R. Hunt and G. Jensen, Pacific Forestry Center, Canadian Forest Service, Victoria, BC; L. Hansen, Warm Springs Indian Reservation, Warm Springs, OR; A. Schick, Naval Submarine Base, Bangor, WA; J. Langhoff, Bureau of Land Management, Medford, OR; and the Genetic Resource Centers, USDA Forest Service Regions 5 and 6. We thank J. Berdeen for organizing and managing the seed collections; A. Mix and G. Dupper for assistance in growing, inoculating, and scoring the seedlings; and N. Rappaport and P. Zambino for critically reviewing an earlier draft of the manuscript.

\section{LITERATURE CITED}

1. Bingham, R. T. 1983. Blister rust resistant white pine for the Inland Empire: The story of the first 25 years of the research and development program. U.S. For. Serv. Intermountain For. Range Exp. Stn. Gen. Tech. Rep. INT-146.

2. Hunt, R. S., and von Rudloff, E. 1977. Leaf-oil terpene variation in western white pine populations of the Pacific Northwest. For. Sci. 23:507-516.

3. Kinloch, B. B., and Dulitz, D. 1990. White pine blister rust at Mountain Home Demonstration State Forest: A case study of the epidemic and prospects for genetic control. U.S. For. Serv. Res. Pap. PSW-204.

4. Kinloch, B. B., Jr. 1992. Distribution and frequency of a gene for resistance to white pine blister rust in natural populations of sugar pine. Can. J. Bot. 70:1319-1323.

5. Kinloch, B. B., Jr., and Comstock, M. 1981. Race of Cronartium ribicola virulent to major gene resistance in sugar pine. Plant Dis. 65:604-605.

6. Kinloch, B. B., Jr., and Dupper, G. E. 2002. Genetic specificity in the white pine-blister rust pathosystem. Phytopathology 92:278-280.

7. Kinloch, B. B., Jr., and Littlefield, J. L. 1977. White pine blister rust: Hypersensitive resistance in sugar pine. Can. J. Bot. 55:1148-1155.

8. Kinloch, B. B., Jr., Sniezko, R. A., Barnes, G. D., and Greathouse, T. E. 1999. A major gene for resistance to white pine blister rust in western white pine from the Western Cascade Range. Phytopathology 89:861867.

9. Ledig, F. T. 1998. Genetic variation in Pinus. Pages 251-280 in: Ecology and Biogeography of Pinus. D. M. Richardson, ed. Cambridge University Press, Cambridge.

10. Neuenschwander, L. F., Byler, J. W., Harvey, A. E., McDonald, G. I., Ortiz, D. S., Osborne, H. L., Snyder, G. C., and Zack, A. 1999. White pine in the American West: A vanishing species_can we save it? U.S. For. Serv. Rocky Mt. Res. Stn. Gen. Tech. Rep. RMRS-GTR-35.

11. Rehfeldt, G. E., Hoff, R. J., and Steinhoff, R. J. 1984. Geographic patterns of genetic variation in Pinus monticola. Bot. Gaz.145:229-239.

12. Steinhoff, R. J., Joyce, D. G., and Fins, L. 1983. Isozyme variation in Pinus monticola. Can. J. For. Res. 13:1122-1132. 